\title{
PERFORMANCE EVALUATION OF RCC BUILDING BY CHANGING THE DESIGN PARAMETERS
}

\author{
Dhaval H. Shinde \\ PG Student, Dept. of Civil Engineering \\ Saraswati College of Engineering, \\ Navi Mumbai, India
}

\author{
Sunil M. Rangari \\ Prof. and Dean Academics \\ Saraswati College of Engineering, \\ Navi Mumbai, India
}

Abstract - Performance based seismic design is a modern day design approach of finding out the reliability of a building during and after a seismic activity. It was used originally for monitoring the performance reliability of old buildings for rehabilitation with seismic provisions. It is an extension to limit state design approach which when analyzed using non-linear static analysis gives the reliable performance level of the building. Performance based seismic design allows us to design the building with a realistic understanding of risk of life, occupancy and economic losses that may occur from future seismic activities. It allows us to construct a building with expected performance in seismic activity.

The non-linear performance level of a RCC building is affected by its design parameters one of which major contributor is the longitudinal and transverse reinforcement present in the columns and the beams of a structure and is also affected by modelling parameters such as nonlinear hinge properties, hinge length etc.

This present study includes analyzing a 5 storeied RCC building using response spectrum analysis for zone III and designing the building for the response spectrum analysis results. The performance point of this building is evaluated using pushover analysis as per FEMA 356 and the plastic hinge behavior is studied. The results are presented in terms of static pushover curve, displacement and hinge status. For shifting the performance of the same building towards lower side, design parameters are changed and performance is evaluated and the results are discussed in terms of percentage change in design parameters.

Keywords - Performance based seismic design, pushover analysis, static pushover curve, plastic hinge, performance point.

\section{INTRODUCTION}

The primary objective of performance based seismic design (PBSD) is to know the actual performance reliability of the design. This method was developed to find out the performance of an existing building with the help of pushover analysis. Pushover analysis is a nonlinear static method in which the building is modelled and pushed up to a pre-determined displacement or pushed with pre-determined forces, and the reliability of the building as a whole as well as behavior of each member are evaluated. This concept of PBSD can also be used for designing and constructing a new building which can tell the expected performance of the building under a particular earthquake. Performance based seismic design can be used for construction of a new building as per the need of the building owner and make the building earthquake resistant as per the functionality of the building for e.g. permanent residential building should not be much damaged during a seismic activity whereas repairable damage can be accepted in a temporary transit camp as compared to a temporary storage go down which will be just structurally stable with irreparable damages during a seismic activity. The cost of construction can be reduced as the materials required for construction would be reduced from a permanent residential building to a temporary transit camp and further more for temporary go down depending on the functionality on the owner.

Performance based seismic design refers to the methodology in which the structural design criteria are expressed in terms of achieving the performance objectives when subjected to stated seismic activity. The performance objectives may be a level of stress, a load, a displacement, a limit state or a target damage state that is not to be exceeded. Target damage state is commonly used criteria of performance objective for PBSD. PBSD permits the design and construction of buildings with a realistic and reliable understanding of the risk to life, occupancy, and economic loss that may occur because of future seismic events. Achieving performance based design is an iterative process which is explained with use of a flowchart as shown in Fig. 1. The owner of the building and the designer will set performance objective or the performance level of the building depending on the functionality of the building. A preliminary designed would be developed and its performance will be evaluated using performance based seismic design. The performance level obtained should match the desired performance objective selected in step 1, if not the preliminary design is modified or redesigned to match the 


\section{International Journal of Engineering Applied Sciences and Technology, 2019 \\ Vol. 4, Issue 4, ISSN No. 2455-2143, Pages 226-234 \\ Published Online August 2019 in IJEAST (http://www.ijeast.com)}

performance objectives. This process continues till the desired performance level is obtained and later the building is constructed. Applied Technology Council 40 document (ATC 40) is limited to concrete buildings and recommends the use of capacity spectrum method, in which the pushover curve (base shear versus roof displacement) is converted into spectral accelerations and spectral displacements (ADRS format) using an equivalent SDOF system. Demand curves are the response spectrum curves for specified damping value, converted into ADRS format. Superposition of capacity curve and demand curve gives the performance point. Fig. 2 explains the process of evaluation of performance point.

Ingale et al. (2017) analysed the performance point of a six storey RCC building considering DBE and MCE for various zones. The building was lying in LS for zone 3 and 4, and in $\mathrm{CP}$ for zone 5, for DBE; and for MCE the building was in $\mathrm{CP}$ for all the zones. Zameeruddin et al. (2016) described the information on the recent developments in performance based seismic design. They explained ATC 40 CSM (Capacity spectrum method), N2 Method, FEMA 273 CSM (Capacity spectrum method), FEMA 440 DCM (Displacement control method) and ASCE 41 DCM (Displacement control method) with their advantages and disadvantages. Akhare et al. (2015) performed standard and modal pushover analysis on $\mathrm{C}, \mathrm{T}$ and $\mathrm{L}$ shaped buildings. They found out that in $\mathrm{L}$ and $\mathrm{T}$ shaped buildings, around $20 \%$ more torsion is generated compared to regular buildings; and concluded that the modal pushover analysis gives more accurate results for irregular buildings. Shinde et al. (2014) used capacity based design to find out the maximum load carrying capacity of members for $\mathrm{G}+3, \mathrm{G}+8$, and G+ 15 RCC buildings and compared it with limit state design. They concluded that capacity based design eliminates the possibility of shear mode of failure by making shear capacity of elements more than their moment capacity. Khan (2014) found out the performance point of a 5 storey RCC building by varying sizes and reinforcement in beams and columns. They concluded that as the sizes are increased, the base shear is increased and roof displacement is decreased.

Eslami et al. (2014) elaborated the difference between FEMA hinge and user defined hinge in terms of the inter-story drift, hinging pattern, failure mechanism, and the pushover curve. They concluded that the difference in moments of the hinges was about $4-7 \%$ for yield point and $12 \%$ for ultimate point. Also, the displacement capacity of user defined hinges is more than the FEMA hinges. Inel et al. (2006) studied the difference between auto defined hinges and the manually defined hinges for pushover analysis. They concluded that the base shear is almost similar with a difference of 5\%. Amount of transverse reinforcement has a large effect on displacement. Both the hinges have a similar yielding pattern. If modelled correctly the auto hinges results are over safe. Auto hinges can give higher deformation capacity than expected if modelled incorrectly.

The review of literature is completed and it is observed that the yielding pattern of the hinges is dependent on the amount of transverse reinforcement provided, spacing of the transverse reinforcement and the modelled hinge length. Modelling of user defined nonlinear hinges produce accurate results compared to auto generated hinges. It is observed from literature review that the performance point of a multi-storey RCC building has only been evaluated; but designing the same building for obtaining various performance levels has not been done so far. Further it is seen from the literature that auto generated hinges as per FEMA 356 are considered in most of the cases; whereas the present study will be based on manually generated hinges which are more effective in evaluating the performance of a structure using pushover analysis.



Fig. 1: Flowchart for performance based seismic design (Zameeruddin, 2016).

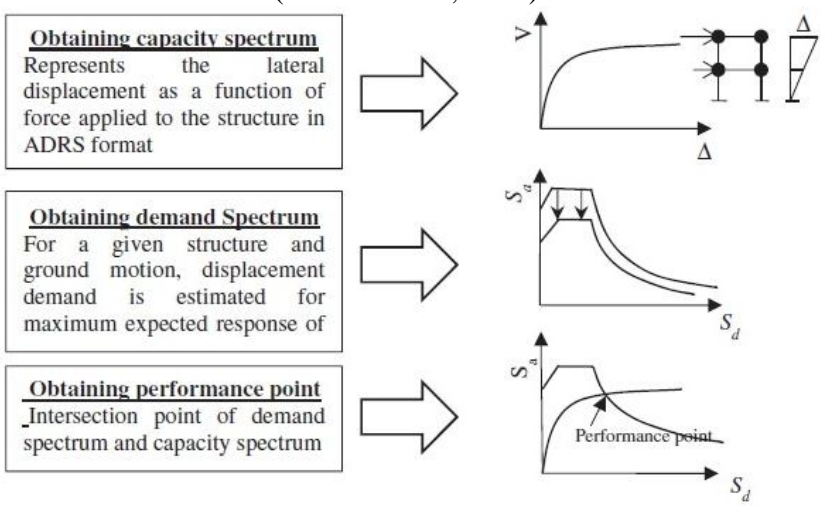

Fig. 2: Determination of performance point (Zameeruddin, 2016).

\section{METHODOLOGY}

The structure is modelled on SAP 2000 V14.2.0. SAP 2000 was selected due to the predefined parameters of ATC 40 for pushover analysis. Manually generated hinges based on moment curvature for particular sections are used rather than 


\section{International Journal of Engineering Applied Sciences and Technology, 2019 \\ Vol. 4, Issue 4, ISSN No. 2455-2143, Pages 226-234 \\ Published Online August 2019 in IJEAST (http://www.ijeast.com)}

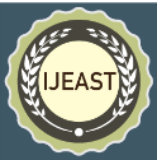

the automatic generated moment rotation hinges. Moment curvatures diagrams are generated from SAP section designer. Moment curvature for beams are based on concrete and its hogging and sagging reinforcement present and that for columns is based on axial loads generating from gravity loads along with concrete and reinforcement present in it. Table I shows the general building data which needs to be inputted for analysis and design.

Table I: Input data.

\begin{tabular}{|l|l|}
\hline Building type & RCC, Residential building \\
\hline $\begin{array}{l}\text { No of bays in X-and } \\
\text { Y-direction }\end{array}$ & 2 Bays @5m c/c in each direction. \\
\hline No of storey & 5 Nos. \\
\hline Floor to floor height & $3 \mathrm{~m}$ \\
\hline Grade of steel & Fe500 \\
\hline Grade of concrete & M30 \\
\hline $\begin{array}{l}\text { Site location, } \\
\text { Seismic Zone }\end{array}$ & Mumbai, Zone III (Z=0.16) \\
\hline $\begin{array}{l}\text { Soil type } \\
\text { Importance factor (I) }\end{array}$ & $\begin{array}{l}\text { II (poorly graded sands or gravelly } \\
\text { sands with little or no fines) }\end{array}$ \\
\hline $\begin{array}{l}\text { Response reduction } \\
\text { factor (R) }\end{array}$ & 5 \\
\hline
\end{tabular}

Pushover analysis is carried out on three models which are named as model 1 , model 2 and model 3 respectively and are explained below. Model 1 is designed to meet the performance level of immediate occupancy. This model is designed using response spectrum analysis as per IS: 1893-2016. Table II and III shows the design results of columns and beams respectively for model 1. Model 2 is designed to meet the performance level of life safety. The model has intermediate design results to match the performance level keeping model 1 as the upper most criteria and model 3 as the lower most criteria. Table IV and $\mathrm{V}$ shows the design results of columns and beams respectively for model 2 . Model 3 is designed to meet the performance level of collapse prevention. This model is designed for gravity loads. The design results obtained can be termed as the lower most sizes of columns and beams. Table VI and VII shows the design results of columns and beams respectively for model 3

Table II: Design results for columns model 1.

\begin{tabular}{|c|c|c|c|c|}
\hline \multirow{3}{*}{ Storey } & \multirow{2}{*}{ Location } & $\begin{array}{c}\text { Cross } \\
\text { Section }\end{array}$ & & \multicolumn{2}{|c|}{ Reinforcement Provided } \\
\cline { 3 - 5 } & & $\begin{array}{c}\text { Main } \\
\text { mm×mm) }\end{array}$ & Reinforcement & $\begin{array}{c}\text { Shear } \\
\text { Reinforcement }\end{array}$ \\
\hline \multirow{3}{*}{1} & Corner & $375 \times 375$ & $16-\phi 16$ & $2 \mathrm{~L}-\phi 10 @ 100 \mathrm{c} / \mathrm{c}$ \\
\cline { 2 - 5 } & Central & $450 \times 450$ & $20-\phi 16$ & $2 \mathrm{~L}-\phi 10 @ 100 \mathrm{c} / \mathrm{c}$ \\
\cline { 2 - 5 } & Rest & $400 \times 400$ & $16-\phi 16$ & $2 \mathrm{~L}-\phi 10 @ 100 \mathrm{c} / \mathrm{c}$ \\
\hline \multirow{3}{*}{2} & Corner & $375 \times 375$ & $16-\phi 16$ & $2 \mathrm{~L}-\phi 10 @ 100 \mathrm{c} / \mathrm{c}$ \\
\cline { 2 - 5 } & Central & $425 \times 425$ & $20-\phi 16$ & $2 \mathrm{~L}-\phi 10 @ 100 \mathrm{c} / \mathrm{c}$ \\
\cline { 2 - 5 } & Rest & $400 \times 400$ & $16-\phi 16$ & $2 \mathrm{~L}-\phi 10 @ 100 \mathrm{c} / \mathrm{c}$ \\
\hline \multirow{3}{*}{3} & Corner & $350 \times 350$ & $12-\phi 16$ & $2 \mathrm{~L}-\phi 10 @ 100 \mathrm{c} / \mathrm{c}$ \\
\cline { 2 - 5 } & Central & $375 \times 375$ & $20-\phi 16$ & $2 \mathrm{~L}-\phi 10 @ 100 \mathrm{c} / \mathrm{c}$ \\
\cline { 2 - 5 } & Rest & $375 \times 375$ & $16-\phi 20$ & $2 \mathrm{~L}-\phi 10 @ 100 \mathrm{c} / \mathrm{c}$ \\
\hline 4 & Corner & $325 \times 325$ & $12-\phi 16$ & $2 \mathrm{~L}-\phi 10 @ 100 \mathrm{c} / \mathrm{c}$ \\
\hline
\end{tabular}

\begin{tabular}{|c|c|c|c|c|}
\hline \multirow{3}{*}{5} & Central & $350 \times 350$ & $12-\phi 16$ & $2 \mathrm{~L}-\phi 10 @ 100 \mathrm{c} / \mathrm{c}$ \\
\cline { 2 - 5 } & Rest & $350 \times 350$ & $12-\phi 16$ & $2 \mathrm{~L}-\phi 10 @ 100 \mathrm{c} / \mathrm{c}$ \\
\hline \multirow{3}{*}{5} & Corner & $325 \times 325$ & $12-\phi 16$ & $2 \mathrm{~L}-\phi 10 @ 100 \mathrm{c} / \mathrm{c}$ \\
\cline { 2 - 5 } & Central & $325 \times 325$ & $12-\phi 12$ & $2 \mathrm{~L}-\phi 10 @ 100 \mathrm{c} / \mathrm{c}$ \\
\cline { 2 - 5 } & Rest & $350 \times 350$ & $16-\phi 12$ & $2 \mathrm{~L}-\phi 10 @ 100 \mathrm{c} / \mathrm{c}$ \\
\hline
\end{tabular}

Table III: Design results for beams model 1.

\begin{tabular}{|c|c|c|c|c|c|}
\hline \multirow{2}{*}{$\begin{array}{l}\text { Stor- } \\
\text { ey }\end{array}$} & \multirow{2}{*}{$\begin{array}{l}\text { Locati- } \\
\text { on }\end{array}$} & \multirow{2}{*}{$\begin{array}{c}\begin{array}{c}\text { Cross } \\
\text { Section } \\
(\mathbf{m m} \times \mathbf{m m})\end{array} \\
\end{array}$} & \multicolumn{2}{|c|}{$\begin{array}{c}\text { Reinforcement } \\
\text { Provided }\end{array}$} & \multirow{2}{*}{$\begin{array}{c}\text { Shear } \\
\text { Reinforcement }\end{array}$} \\
\hline & & & Top & Bottom & \\
\hline \multirow{2}{*}{1} & Central & $230 \times 400$ & $5-\phi 16$ & $3-\phi 16$ & $2 \mathrm{~L}-\phi 10 @ 100 \mathrm{c} / \mathrm{c}$ \\
\hline & Corner & $230 \times 400$ & $4-\phi 16$ & $2-\phi 16$ & $2 \mathrm{~L}-\phi 10 @ 100 \mathrm{c} / \mathrm{c}$ \\
\hline \multirow{2}{*}{2} & Central & $230 \times 400$ & $5-\phi 16$ & $3-\phi 16$ & $2 \mathrm{~L}-\phi 10 @ 100 \mathrm{c} / \mathrm{c}$ \\
\hline & Corner & $230 \times 400$ & $5-\phi 16$ & $3-\phi 16$ & $2 \mathrm{~L}-\phi 10 @ 100 \mathrm{c} / \mathrm{c}$ \\
\hline \multirow{2}{*}{3} & Central & $230 \times 400$ & $5-\phi 16$ & $3-\phi 16$ & $2 \mathrm{~L}-\phi 10 @ 100 \mathrm{c} / \mathrm{c}$ \\
\hline & Corner & $230 \times 400$ & $4-\phi 16$ & $2-\phi 16$ & $2 \mathrm{~L}-\phi 10 @ 100 \mathrm{c} / \mathrm{c}$ \\
\hline \multirow{2}{*}{4} & Central & $230 \times 400$ & $4-\phi 16$ & $2-\phi 16$ & $2 \mathrm{~L}-\phi 10 @ 100 \mathrm{c} / \mathrm{c}$ \\
\hline & Corner & $230 \times 400$ & $4-\phi 16$ & $2-\phi 16$ & $2 \mathrm{~L}-\phi 10 @ 100 \mathrm{c} / \mathrm{c}$ \\
\hline \multirow{2}{*}{5} & Central & $230 \times 400$ & $3-\phi 16$ & $3-\phi 16$ & $2 \mathrm{~L}-\phi 10 @ 100 \mathrm{c} / \mathrm{c}$ \\
\hline & Corner & $230 \times 400$ & $3-\phi 16$ & $2-\phi 16$ & $2 \mathrm{~L}-\phi 10 @ 100 \mathrm{c} / \mathrm{c}$ \\
\hline
\end{tabular}

Table IV: Design results for columns model 2.

\begin{tabular}{|c|c|c|c|c|}
\hline \multirow[b]{2}{*}{$\begin{array}{l}\text { Stor- } \\
\text { ey }\end{array}$} & \multirow[b]{2}{*}{ Location } & \multirow{2}{*}{$\begin{array}{c}\text { Cross } \\
\text { Section } \\
(\mathbf{m m} \times \mathbf{m m})\end{array}$} & \multicolumn{2}{|c|}{ Reinforcement Provided } \\
\hline & & & $\begin{array}{c}\text { Main } \\
\text { Reinforcement }\end{array}$ & $\begin{array}{c}\text { Shear } \\
\text { Reinforcement }\end{array}$ \\
\hline \multirow{3}{*}{1} & Corner & $350 \times 350$ & $16-\phi 12$ & $3 \mathrm{~L}-\phi 10 @ 100 \mathrm{c} / \mathrm{c}$ \\
\hline & Central & $425 \times 425$ & $16-\phi 16$ & $3 \mathrm{~L}-\phi 10 @ 100 \mathrm{c} / \mathrm{c}$ \\
\hline & Rest & $375 \times 375$ & $12-\phi 16$ & $3 \mathrm{~L}-\phi 10 @ 100 \mathrm{c} / \mathrm{c}$ \\
\hline \multirow{3}{*}{2} & Corner & $350 \times 350$ & $12-\phi 16$ & $3 \mathrm{~L}-\phi 10 @ 100 \mathrm{c} / \mathrm{c}$ \\
\hline & Central & $400 \times 400$ & $16-\phi 16$ & $3 \mathrm{~L}-\phi 10 @ 100 \mathrm{c} / \mathrm{c}$ \\
\hline & Rest & $375 \times 375$ & $16-\phi 16$ & $3 \mathrm{~L}-\phi 10 @ 100 \mathrm{c} / \mathrm{c}$ \\
\hline \multirow{3}{*}{3} & Corner & $325 \times 325$ & $16-\phi 12$ & $3 \mathrm{~L}-\phi 10 @ 100 \mathrm{c} / \mathrm{c}$ \\
\hline & Central & $350 \times 350$ & $16-\phi 16$ & $3 \mathrm{~L}-\phi 10 @ 100 \mathrm{c} / \mathrm{c}$ \\
\hline & Rest & $350 \times 350$ & $12-\phi 16$ & $3 \mathrm{~L}-\phi 10 @ 100 \mathrm{c} / \mathrm{c}$ \\
\hline \multirow{3}{*}{4} & Corner & $300 \times 300$ & $16-\phi 12$ & $2 \mathrm{~L}-\phi 10 @ 100 \mathrm{c} / \mathrm{c}$ \\
\hline & Central & $325 \times 325$ & $16-\phi 12$ & $2 \mathrm{~L}-\phi 10 @ 100 \mathrm{c} / \mathrm{c}$ \\
\hline & Rest & $325 \times 325$ & $16-\phi 12$ & $2 \mathrm{~L}-\phi 10 @ 100 \mathrm{c} / \mathrm{c}$ \\
\hline \multirow{3}{*}{5} & Corner & $300 \times 300$ & $16-\phi 12$ & $2 \mathrm{~L}-\phi 10 @ 100 \mathrm{c} / \mathrm{c}$ \\
\hline & Central & $300 \times 300$ & $12-\phi 12$ & $2 \mathrm{~L}-\phi 10 @ 100 \mathrm{c} / \mathrm{c}$ \\
\hline & Rest & $325 \times 325$ & $12-\phi 12$ & 2 L- $\phi 10 @ 100 \mathrm{c} / \mathrm{c}$ \\
\hline
\end{tabular}

Table V: Design results for beams model 2.

\begin{tabular}{|c|c|c|c|c|c|}
\hline \multirow{2}{*}{$\begin{array}{l}\text { Stor } \\
\text {-ey }\end{array}$} & \multirow{2}{*}{$\begin{array}{l}\text { Locati } \\
\text {-on }\end{array}$} & \multirow{2}{*}{$\begin{array}{c}\text { Cross } \\
\text { Section } \\
(\mathbf{m m} \times \mathbf{m m})\end{array}$} & \multicolumn{2}{|c|}{$\begin{array}{c}\text { Reinforcement } \\
\text { Provided }\end{array}$} & \multirow{2}{*}{$\begin{array}{c}\text { Shear } \\
\text { Reinforcement }\end{array}$} \\
\hline & & & Top & Bottom & \\
\hline \multirow{2}{*}{1} & Central & $230 \times 375$ & $2-\phi 16$ & $2-\phi 16$ & $2 \mathrm{~L}-\phi 10 @ 100 \mathrm{c} / \mathrm{c}$ \\
\hline & Corner & $230 \times 375$ & $2-\phi 16$ & $2-\phi 16$ & 2 L- $\phi 10 @ 100 \mathrm{c} / \mathrm{c}$ \\
\hline \multirow{2}{*}{2} & Central & $230 \times 375$ & $2-\phi 16$ & $2-\phi 16$ & 2 L- $\phi 10 @ 100 \mathrm{c} / \mathrm{c}$ \\
\hline & Corner & $230 \times 375$ & $2-\phi 16$ & $2-\phi 16$ & $2 \mathrm{~L}-\phi 10 @ 100 \mathrm{c} / \mathrm{c}$ \\
\hline \multirow{2}{*}{3} & Central & $230 \times 375$ & $2-\phi 16$ & $2-\phi 16$ & $2 \mathrm{~L}-\phi 10 @ 100 \mathrm{c} / \mathrm{c}$ \\
\hline & Corner & $230 \times 375$ & $2-\phi 16$ & $2-\phi 16$ & $2 \mathrm{~L}-\phi 10 @ 100 \mathrm{c} / \mathrm{c}$ \\
\hline \multirow{2}{*}{4} & Central & $230 \times 375$ & $2-\phi 16$ & $2-\phi 16$ & $2 \mathrm{~L}-\phi 10 @ 100 \mathrm{c} / \mathrm{c}$ \\
\hline & Corner & $230 \times 375$ & $2-\phi 16$ & $2-\phi 16$ & $2 \mathrm{~L}-\phi 10 @ 100 \mathrm{c} / \mathrm{c}$ \\
\hline \multirow{2}{*}{5} & Central & $230 \times 375$ & $2-\phi 16$ & $2-\phi 16$ & $2 \mathrm{~L}-\phi 10 @ 100 \mathrm{c} / \mathrm{c}$ \\
\hline & Corner & $230 \times 375$ & $2-\phi 16$ & $2-\phi 16$ & $2 \mathrm{~L}-\phi 10 @ 100 \mathrm{c} / \mathrm{c}$ \\
\hline
\end{tabular}




\section{International Journal of Engineering Applied Sciences and Technology, 2019 \\ Vol. 4, Issue 4, ISSN No. 2455-2143, Pages 226-234 \\ Published Online August 2019 in IJEAST (http://www.ijeast.com)}

Table VI: Design results for columns model 3.

\begin{tabular}{|c|c|c|c|c|}
\hline \multirow{2}{*}{$\begin{array}{c}\text { Stor- } \\
\text { ey }\end{array}$} & \multirow[b]{2}{*}{ Location } & \multirow{2}{*}{$\begin{array}{c}\begin{array}{c}\text { Cross } \\
\text { Section } \\
(\mathbf{m m} \times \mathbf{m m})\end{array} \\
\end{array}$} & \multicolumn{2}{|c|}{ Reinforcement Provided } \\
\hline & & & $\begin{array}{c}\text { Main } \\
\text { Reinforcement }\end{array}$ & $\begin{array}{c}\text { Shear } \\
\text { Reinforcement }\end{array}$ \\
\hline \multirow{3}{*}{1} & Corner & $300 \times 300$ & $8-\phi 12$ & $2 \mathrm{~L}-\phi 10 @ 100 \mathrm{c} / \mathrm{c}$ \\
\hline & Central & $350 \times 350$ & $12-\phi 16$ & $2 \mathrm{~L}-\phi 10 @ 100 \mathrm{c} / \mathrm{c}$ \\
\hline & Rest & $325 \times 325$ & $8-\phi 16$ & $2 \mathrm{~L}-\phi 10 @ 100 \mathrm{c} / \mathrm{c}$ \\
\hline \multirow{3}{*}{2} & Corner & $300 \times 300$ & $8-\phi 16$ & $2 \mathrm{~L}-\phi 10 @ 100 \mathrm{c} / \mathrm{c}$ \\
\hline & Central & $325 \times 325$ & $8-\phi 10$ & $2 \mathrm{~L}-\phi 10 @ 100 \mathrm{c} / \mathrm{c}$ \\
\hline & Rest & $325 \times 325$ & $12-\phi 16$ & $2 \mathrm{~L}-\phi 10 @ 100 \mathrm{c} / \mathrm{c}$ \\
\hline \multirow{3}{*}{3} & Corner & $300 \times 300$ & $8-\phi 12$ & $2 \mathrm{~L}-\phi 10 @ 100 \mathrm{c} / \mathrm{c}$ \\
\hline & Central & $300 \times 300$ & $16-\phi 12$ & $2 \mathrm{~L}-\phi 10 @ 100 \mathrm{c} / \mathrm{c}$ \\
\hline & Rest & $300 \times 300$ & $16-\phi 12$ & $2 \mathrm{~L}-\phi 10 @ 100 \mathrm{c} / \mathrm{c}$ \\
\hline \multirow{3}{*}{4} & Corner & $275 \times 275$ & $8-\phi 12$ & $2 \mathrm{~L}-\phi 10 @ 100 \mathrm{c} / \mathrm{c}$ \\
\hline & Central & $275 \times 275$ & $8-\phi 12$ & $2 \mathrm{~L}-\phi 10 @ 100 \mathrm{c} / \mathrm{c}$ \\
\hline & Rest & $275 \times 275$ & $8-\phi 12$ & 2 L- $\phi 10 @ 100 \mathrm{c} / \mathrm{c}$ \\
\hline \multirow{3}{*}{5} & Corner & $250 \times 250$ & $12-\phi 12$ & $2 \mathrm{~L}-\phi 10 @ 100 \mathrm{c} / \mathrm{c}$ \\
\hline & Central & $250 \times 250$ & $8-\phi 10$ & $2 \mathrm{~L}-\phi 10 @ 100 \mathrm{c} / \mathrm{c}$ \\
\hline & Rest & $250 \times 250$ & $8-\phi 12$ & $2 \mathrm{~L}-\phi 10 @ 100 \mathrm{c} / \mathrm{c}$ \\
\hline
\end{tabular}

Table VII: Design results for beams model 3.

\begin{tabular}{|c|c|c|c|c|c|}
\hline \multirow{2}{*}{$\begin{array}{l}\text { Stor- } \\
\text { ey }\end{array}$} & \multirow{2}{*}{$\begin{array}{l}\text { Locati } \\
\text {-on }\end{array}$} & \multirow{2}{*}{$\begin{array}{c}\text { Cross } \\
\text { Section } \\
(\mathbf{m m} \times \mathbf{m m})\end{array}$} & \multicolumn{2}{|c|}{$\begin{array}{l}\text { Reinforcement } \\
\text { Provided }\end{array}$} & \multirow{2}{*}{$\begin{array}{c}\text { Shear } \\
\text { Reinforcement }\end{array}$} \\
\hline & & & Top & Bottom & \\
\hline \multirow{2}{*}{1} & Central & $230 \times 350$ & $3-\phi 12$ & $2-\phi 12$ & $2 \mathrm{~L}-\phi 10 @ 100 \mathrm{c} / \mathrm{c}$ \\
\hline & Corner & $230 \times 350$ & $3-\phi 12$ & $2-\phi 12$ & $2 \mathrm{~L}-\phi 10 @ 100 \mathrm{c} / \mathrm{c}$ \\
\hline \multirow{2}{*}{2} & Central & $230 \times 350$ & $3-\phi 12$ & $2-\phi 12$ & $2 \mathrm{~L}-\phi 10 @ 100 \mathrm{c} / \mathrm{c}$ \\
\hline & Corner & $230 \times 350$ & $3-\phi 12$ & $2-\phi 12$ & $2 \mathrm{~L}-\phi 10 @ 100 \mathrm{c} / \mathrm{c}$ \\
\hline \multirow{2}{*}{3} & Central & $230 \times 350$ & $3-\phi 12$ & $2-\phi 12$ & $2 \mathrm{~L}-\phi 10 @ 100 \mathrm{c} / \mathrm{c}$ \\
\hline & Corner & $230 \times 350$ & $3-\phi 12$ & $2-\phi 12$ & $2 \mathrm{~L}-\phi 10 @ 100 \mathrm{c} / \mathrm{c}$ \\
\hline \multirow{2}{*}{4} & Central & $230 \times 350$ & $3-\phi 12$ & $2-\phi 12$ & $2 \mathrm{~L}-\phi 10 @ 100 \mathrm{c} / \mathrm{c}$ \\
\hline & Corner & $230 \times 350$ & $3-\phi 12$ & $2-\phi 12$ & $2 \mathrm{~L}-\phi 10 @ 100 \mathrm{c} / \mathrm{c}$ \\
\hline \multirow{2}{*}{5} & Central & $230 \times 350$ & $3-\phi 12$ & $2-\phi 12$ & $2 \mathrm{~L}-\phi 10 @ 100 \mathrm{c} / \mathrm{c}$ \\
\hline & Corner & $230 \times 350$ & $3-\phi 12$ & $2-\phi 12$ & $2 \mathrm{~L}-\phi 10 @ 100 \mathrm{c} / \mathrm{c}$ \\
\hline
\end{tabular}

Pushover analysis is a process to estimate the strength capacity of a structure beyond its elastic limit. Weak areas in the structure can be predicted by observing the yielding of hinges. Hinges are points on a structure where one expects cracking and yielding to occur in relatively higher intensity so that they show high flexural displacement.

\section{Capacity Curve}

Pushover curve is the plot between base shear and roof displacement when the structure is pushed from its original position till the assigned displacement or a failure mechanism is created. This pushover curve is converted into spectral coordinates i.e. spectral acceleration and spectral displacement as per steps provided in ATC 40. This curve in spectral coordinates is called as capacity curve.

Bilinear representation of capacity curve is needed to calculate the effective damping, which would be further used to determine the appropriate reduction of spectral demand.

\section{Demand Curve}

Response spectrum is the curve between spectral acceleration and time period. The demand curve is obtained by converting the response spectrum curve into spectral acceleration versus spectral displacement format having radial lines indicating time period. The response spectrum is potted as per ATC 40, using coefficient $C_{\square}$ and $C_{v}$. These values depend on the zone, type of earthquake considered for analysis, soil conditions, seismic source and its distance from the building.

\section{Performance Point}

Performance point the point on the capacity curve which gives the spectral acceleration and spectral displacement the building would be acted upon during an earthquake event representing the demand. The spectral acceleration and spectral displacement can be easily converted into base shear and roof displacement. The verification of performance objective of the building will be dependent on the performance point of the structure. Every structure will have a different performance point for the same earthquake event.

\section{RESULTS AND DISCUSSION}

\section{A. Pushover Curves}

Pushover curves for model 1, 2 and 3 are shown in fig. 3,5 and 7 respectively. Fig. 4, 6 and 8 shows performance points for model 1, 2 and 3 respectively. The load carrying capacity of the structure reduces from model 1 to model 2 and from model 2 to model 3 which means model 1 is the strongest structure and model 3 is the weakest structure indicated by the base shear values of pushover curves. Performance point for model 1, model 2 and model 3 is 81 $\mathrm{mm}, 143 \mathrm{~mm}$ and $201 \mathrm{~mm}$ respectively.

\section{B. Inter-storey Drift}

Inter-storey drift for displacements obtained on performance point for all the three models as shown in Table VIII. The maximum inter-storey drift of the structure for model 1 is 0.008 which is less than 0.01 hence this model has its global performance level in IO. Model 2 has its maximum inter-storey drift greater than 0.01 hence it has its global performance level in LS. Model 3 has its maximum interstorey drift equal to 0.020 hence it can be termed as CP.

\section{Yielding of Hinges}

Fig. 9, 11, 13 and 10,12, 14 shows the yielding of hinges on the back bone defined manually using moment curvature of the section for beams and columns respectively for all the 3 models. The hinges of beams and columns in model 1 are yielded to a maximum of IO and that for model 2 and 3 are yielded to a maximum of LS on performance point.

\section{Hinging Pattern}

After pushover analysis hinges are formed all over the structure. Fig.15, 16 and 17 show the hinges formed on model 1,2 and 3 respectively. In model 1 all the hinges are pink hinges indicating yielded to B - IO. In model 2 there are blue hinges along with pink hinges indicating yielded to IO - LS. 


\section{International Journal of Engineering Applied Sciences and Technology, 2019 \\ Vol. 4, Issue 4, ISSN No. 2455-2143, Pages 226-234 \\ Published Online August 2019 in IJEAST (http://www.ijeast.com)}

In model 3 the number of blue hinges have increased and the pink hinges have decreased. Hinges are seen more in beams than in the columns in all the three models indicating strong column weak beam action.

\section{E. Hinge Status}

Hinges are formed as the displacement goes on increasing. In model 1 there are 47 hinges formed in the structure on performance point step and they lie in B - IO. In model 2 there are 23 hinges in B - IO and 27 hinges have yielding beyond IO but are not yielded till LS on performance point. In model 3 there are 14 hinges in $\mathrm{B}-\mathrm{IO}$ and 51 hinges have yielding beyond IO but are not yielded till LS on performance point.



Fig. 3: Pushover curve for model 1.

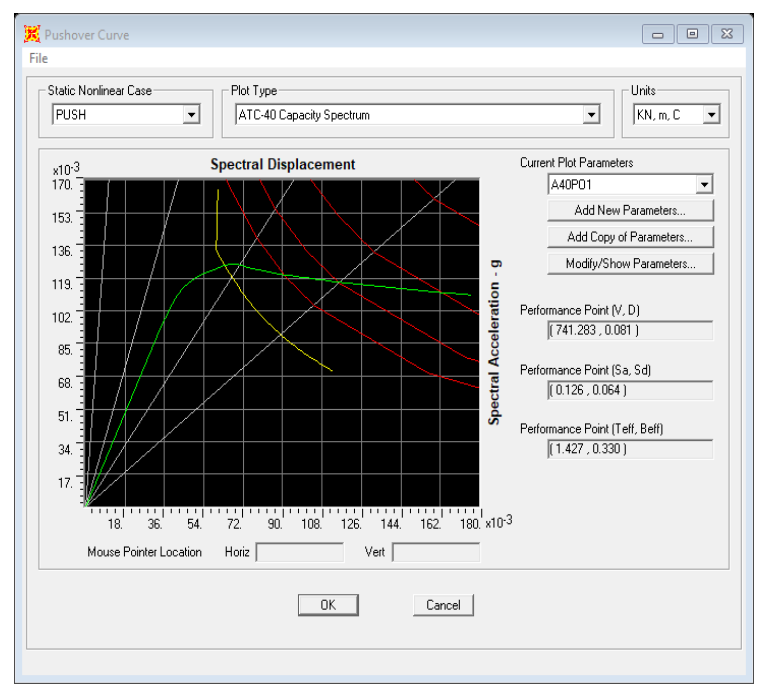

Fig. 4: Performance point for model 1.

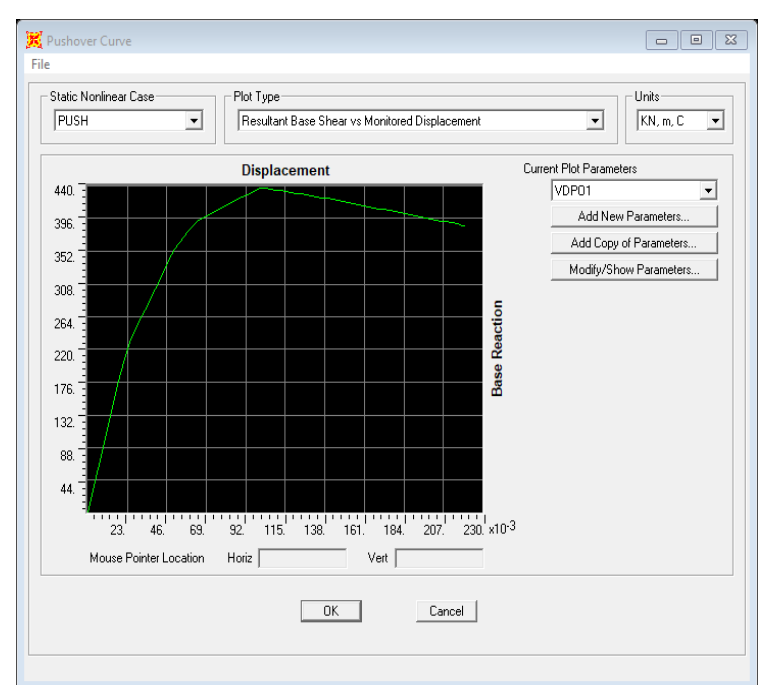

Fig. 5: Pushover curve for model 2.

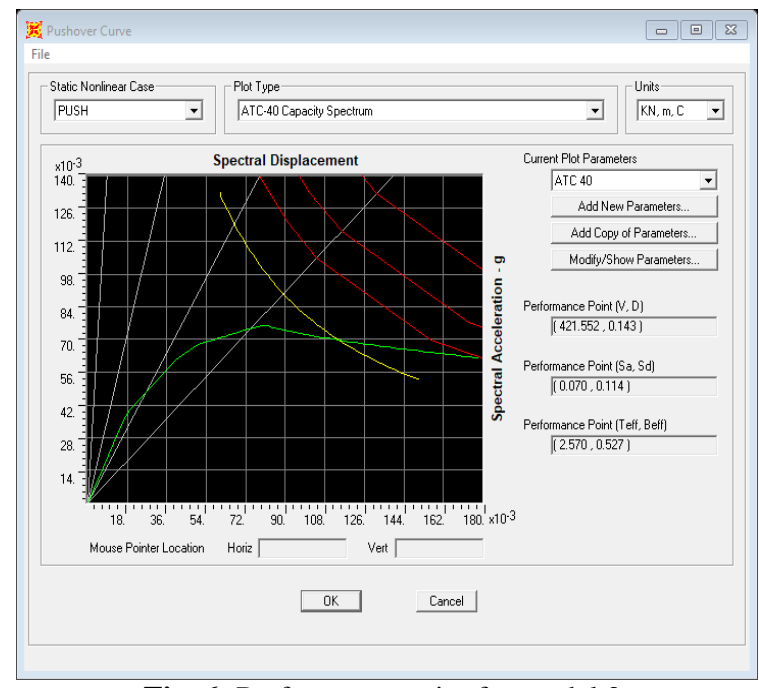

Fig. 6: Performance point for model 2.

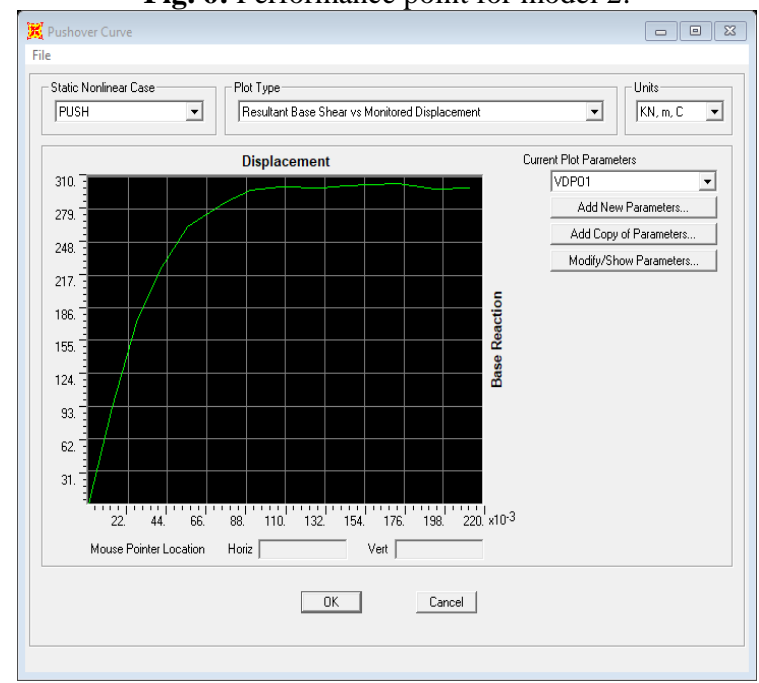

Fig. 7: Pushover curve for model 3. 
International Journal of Engineering Applied Sciences and Technology, 2019

Vol. 4, Issue 4, ISSN No. 2455-2143, Pages 226-234

Published Online August 2019 in IJEAST (http://www.ijeast.com)

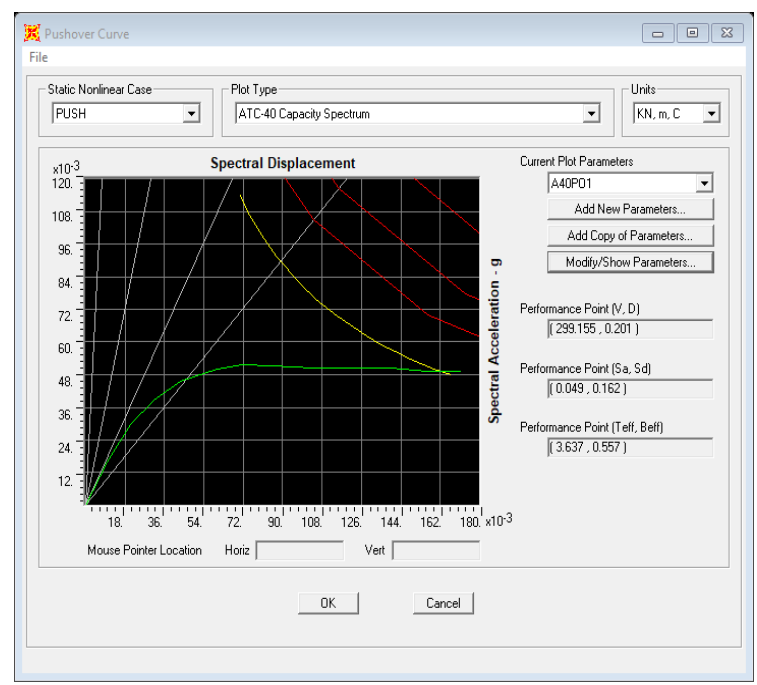

Fig. 8: Performance point for model 2.

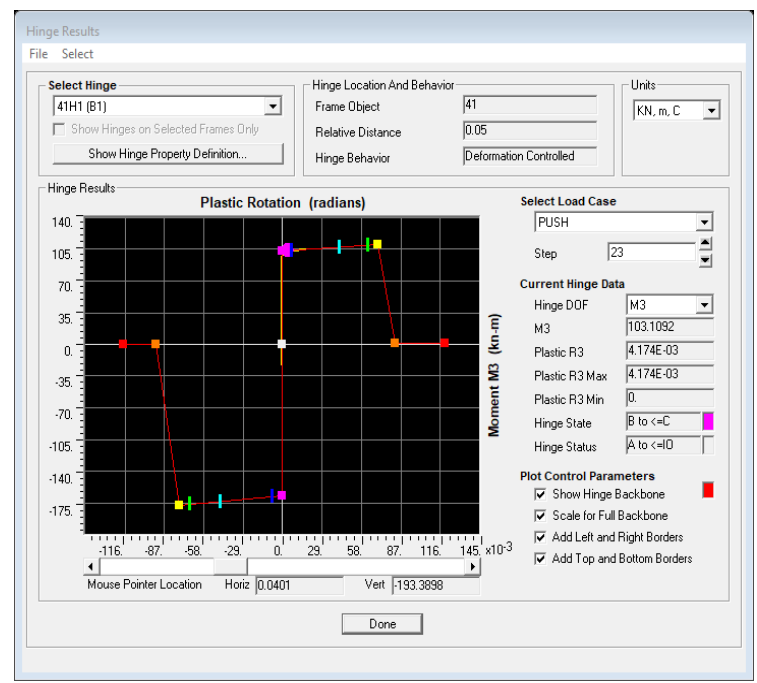

Fig. 9: Beam hinge for model 1.



Fig. 10: Column hinge for model 1.

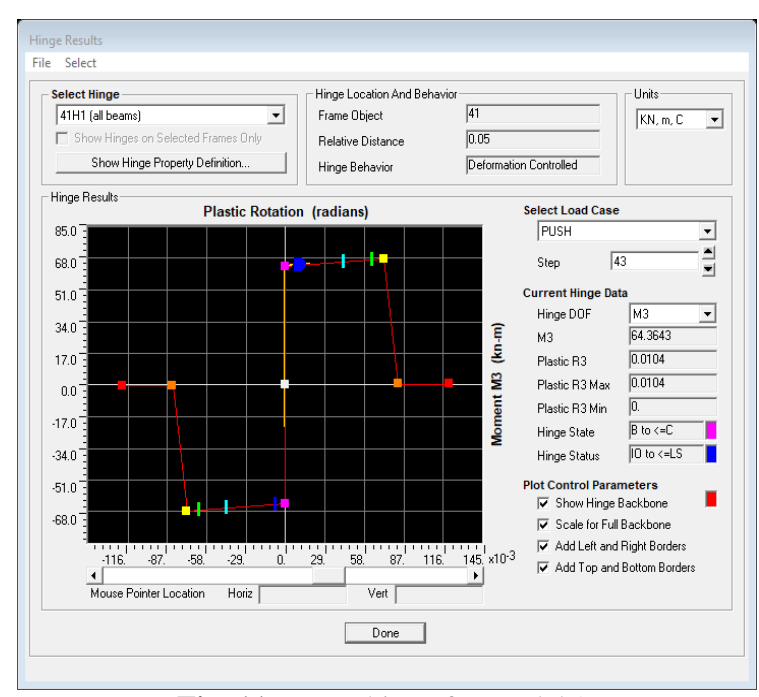

Fig. 11: Beam hinge for model 2.

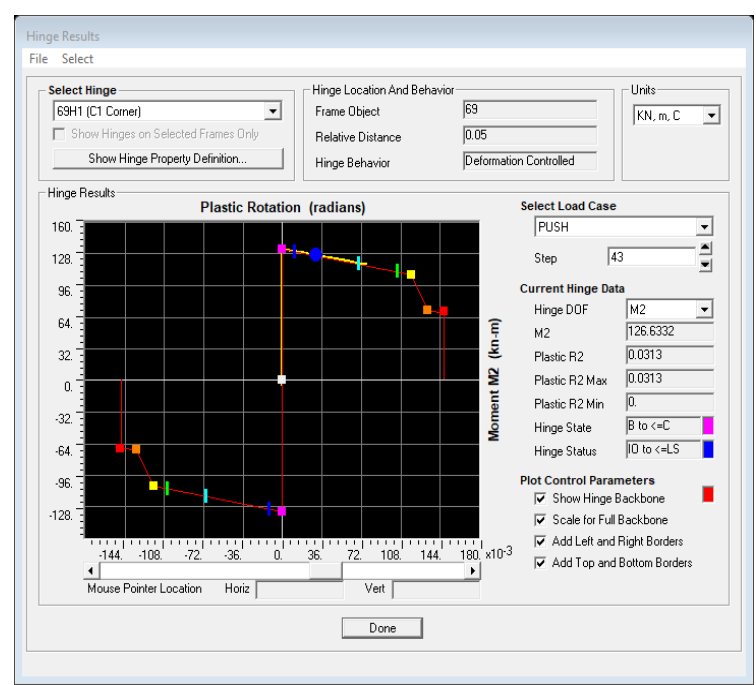

Fig. 12: Column hinge for model 1.




Fig. 13: Beam hinge for model 3.

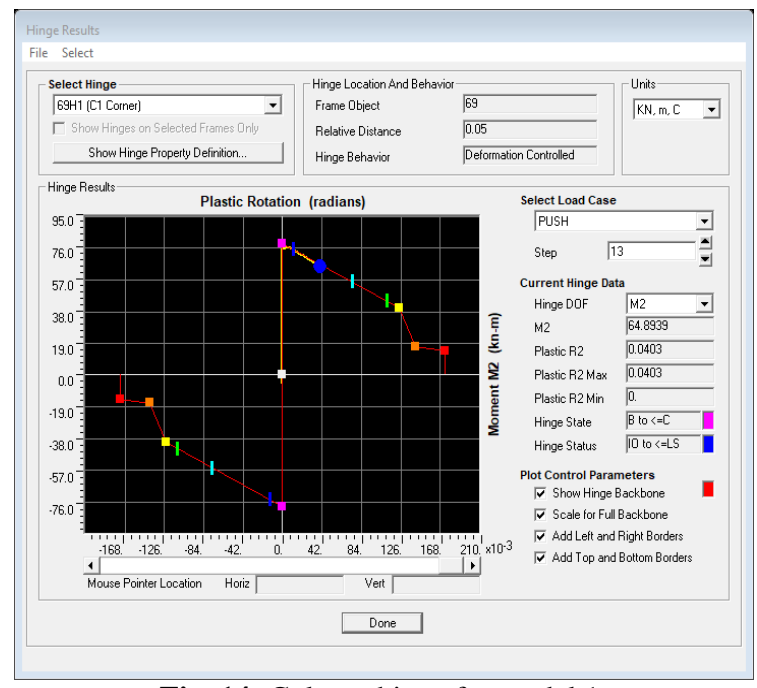

Fig. 14: Column hinge for model 1.
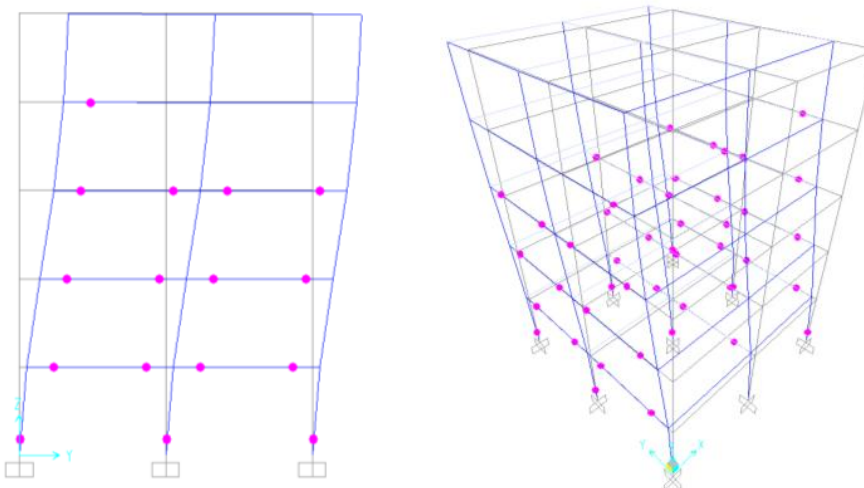

Fig. 15: Hinges on model 1.
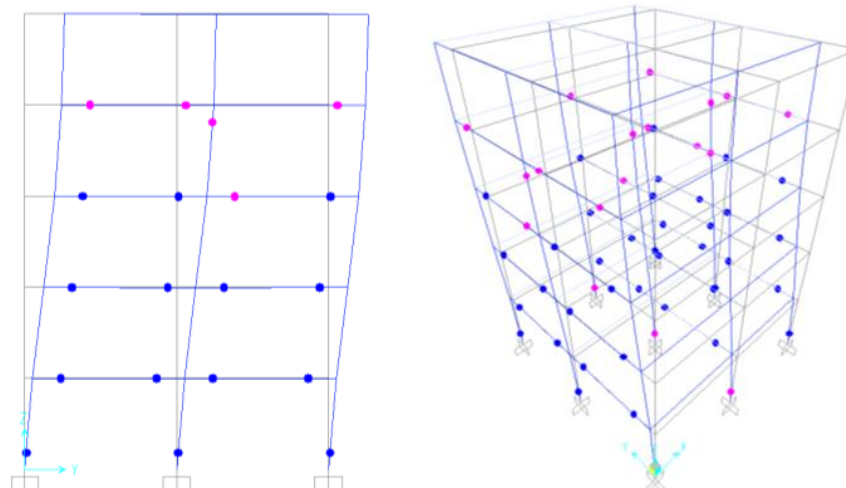

Fig. 16: Hinges on model 2.
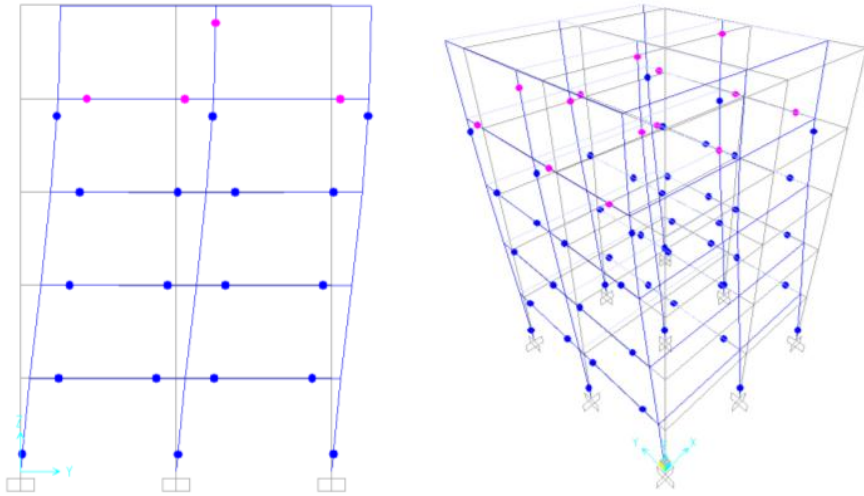

Fig. 17: Hinges on model 3.

Table VIII: Inter-storey drift at performance point.

\begin{tabular}{|c|c|c|c|c|c|c|}
\hline \multirow{2}{*}{ Storey } & \multicolumn{2}{|c|}{ Model 1 } & \multicolumn{2}{c|}{ Model 2 } & \multicolumn{2}{c|}{ Model 3 } \\
\cline { 2 - 7 } & $\boldsymbol{\Delta} \mathbf{( m m )}$ & $\begin{array}{c}\text { Inter- } \\
\text { storey } \\
\text { Drift }\end{array}$ & $\begin{array}{c}\boldsymbol{\Delta} \\
(\mathbf{m m})\end{array}$ & $\begin{array}{c}\text { Inter- } \\
\text { storey } \\
\text { Drift }\end{array}$ & $\begin{array}{c}\boldsymbol{\Delta} \\
(\mathbf{m m})\end{array}$ & $\begin{array}{c}\text { Inter- } \\
\text { storey } \\
\text { Drift }\end{array}$ \\
\hline 5 & 84.07 & 0.003 & 145.37 & 0.003 & 213.03 & 0.004 \\
\hline 4 & 76.03 & 0.006 & 135.40 & 0.009 & 200.94 & 0.013 \\
\hline 3 & 59.15 & 0.008 & 109.39 & 0.013 & 162.79 & 0.018 \\
\hline 2 & 35.68 & 0.008 & 69.41 & 0.014 & 108.10 & 0.020 \\
\hline 1 & 12.68 & 0.004 & 28.14 & 0.009 & 48.72 & 0.016 \\
\hline F & 0.00 & 0.000 & 0.00 & 0.000 & 0.00 & 0.000 \\
\hline \multicolumn{2}{|c|}{ Maximum Inter- } & 0.008 & & $0.01<$ & & 0.020 \\
storey Drift & $\leq 0.01$ & & $0.014 \leq$ & & $\geq 0.02$ \\
\hline
\end{tabular}

\section{F. Comparison of Results}

1. Comparison of Results of present study with Inel (2006).

Hinging Pattern of the hinges formed on this structure in this study can be compared with hinging pattern in the paper published by Inel (2006). Fig.18 shows the hinges formed on model 1 of this study compared to fig. 19 shows the hinges formed on the structure on the published paper. Hinges in both the cases are just yielded as shown by pink colour on fig. 18 and a round symbol on fig. 19. Hinges are mainly formed on beams and columns of lowermost storey in both the cases. 


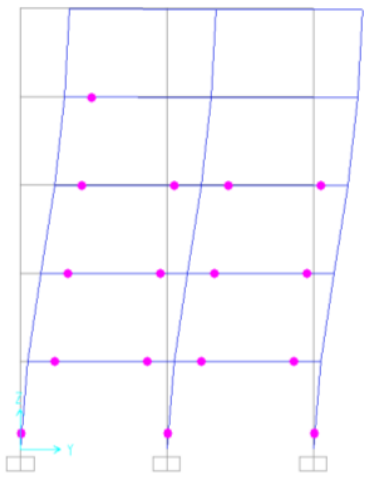

Fig. 18: Hinging pattern of current study.



Fig. 19: Hinging pattern of Inel (2006).

\section{Comparison of Results of present study with Ingale} (2017).

The change in base shear with increasing displacement when the structure is pushed is compared with the results obtained by Ingale (2017). Table IX shows the value of increasing displacement. The base shear values in the present study are smaller as compared to those of Ingale because the seismic weight considered by him is very large as compared to the present study. An increasing base shear is observed in the results obtained by Ingale (2017) this is because the structure is assumed to have sizes of beams and columns as $500 \times 600$ where as in the present study the sizes of columns and beams are designed and optimized as per analysis results of response spectrum.

Table IX: Comparison of base shear with Ingale (2017).

\begin{tabular}{|c|c|c|}
\hline \multirow{2}{*}{ Displacement (mm) } & \multicolumn{2}{|c|}{ Base Shear(kN) } \\
\cline { 2 - 3 } & Present Study & Ingale (2017) \\
\hline 0 & 0 & 0 \\
\hline 20 & 259.65 & 4000 \\
\hline 40 & 482.06 & 7000 \\
\hline 60 & 676.22 & 7750 \\
\hline 80 & 740.16 & 8500 \\
\hline 100 & 745.716 & 8750 \\
\hline 120 & 739.53 & 8800 \\
\hline 140 & 731.75 & 8850 \\
\hline 160 & 724.7 & 8900 \\
\hline 180 & 716.41 & 9000 \\
\hline 200 & 706.44 & 9100 \\
\hline
\end{tabular}

\section{CONCLUSIONS}

Based on the results obtained in the present study, following conclusions are drawn.
1. The global performance point of the structure designed using response spectrum analysis is found out which lies in immediate occupancy performance level.

2. The amount of concrete and steel required for columns and beams of the building designed using response spectrum analysis is $45.7 \mathrm{~m}^{3}$ and 7.507 tons respectively.

3. The amount of concrete and steel required for the building to be designed for life safety performance level is $41.60 \mathrm{~m}^{3}$ and 5.836 tons respectively i.e. $8.98 \%$ reduction in amount of concrete and $22.28 \%$ reduction in amount of steel as compared to the quantities obtained for a building designed using response spectrum analysis.

4. Building designed only to resist gravity loads has structural stability or collapse prevention performance level.

5. The amount of concrete and steel required for the building to be designed for structural safety or collapse prevention performance level is $35.69 \mathrm{~m}^{3}$ and 4.259 tons respectively i.e. $21.91 \%$ reduction in amount of concrete and $43.27 \%$ reduction in amount of steel as compared to the quantities obtained for a building designed using response spectrum analysis.

6. Hinges are first formed in beams indicating strong column weak beam structure.

\section{REFERENCE}

[1]. IS 1893 (Part 1):2002, “Criteria for Earthquake Resistant Design of Structures", Fifth Revision, Bureau of Indian Standards, New Delhi, India.

[2]. IS 875 (Part 2):1987, Reaffirmed 2008, "Code of Practise for Design Load (Other than Earthquake) for Building and Structures", Second Revision, Bureau of Indian Standards, New Delhi, India.

[3]. ATC 40, (2001), "Seismic evaluation and retrofit of concrete buildings Volume 1", California Seismic Safety Commission.

[4]. ASCE 41-17, (2017), "Seismic Evaluation and Retrofit of Existing Buildings", American Society of Civil Engineers.

[5]. FEMA 273, (1997), "NEHRP guidelines for the seismic rehabilitation of buildings", American Society of Civil Engineers.

[6]. FEMA 274, (1997), "NEHRP Commentary on the guidelines for the seismic rehabilitation of buildings", American Society of Civil Engineers.

[7]. FEMA 356, (2000), "Pre-standard and commentary for the seismic rehabilitation of buildings", American Society of Civil Engineers.

[8]. FEMA 440, (2005), "Improvement of Nonlinear Static Seismic Analysis Procedures", American Society of Civil Engineers. 
[9]. FEMA 445, (2006), "Next-Generation PerformanceBased Seismic Design Guidelines", American Society of Civil Engineers.

[10]. FEMA 695, (2009), "Quantification of Building Seismic Performance Factors", American Society of Civil Engineers.

[11]. FEMA P-751, (2009) "2009 NEHRP Recommended Seismic Provisions: Design Examples", American Society of Civil Engineers.

[12]. Mario Paz, "Structural Dynamics", CBS Publishers, Second Edition.

[13]. Ashish, A., and Maske, A., (2005), "Performance based seismic design of RCC buildings with plan irregularity", Journal of civil engineering and environmental technology, Volume 2, Number 10, pp. 1-6.

[14]. Eslami, A., and Ronagh, H., (2014), "Effect of elaborate plastic hinge definition on the pushover analysis of reinforced concrete buildings", The Structural Design of Tall and Special Buildings, Volume 23, Number 4, pp 254-271.

[15]. Ghobarah A., (2005), "Performance Based Design of Earthquake Engineering: state of development", Engineering Structures, Volume 23, Number 8, pp 878884.

[16]. Inel, M., and Hairy. B., (2006), "Effects of plastic hinge properties in nonlinear analysis of reinforced concrete buildings", Engineering Structure, Volume 28, Number 11, pp 1494-1502.

[17]. Ingale, C., and Nalamwar, M., (2017), "Performance based seismic design of RCC buildings", International research journal of Engineering and technology, Volume 4, Number 10, pp 618-623.

[18]. Javiya, S., and Bhibhuti, B., (2017), "Performance Based Analysis of RCC building", International Journal of Advance Engineering and Research Development, Volume 4, Number 4, pp 641-648.

[19]. Khan, R., (2014), "Performance based seismic design of reinforced concrete buildings" International Journal of Innovative Research in Science, Engineering and Technology, Volume 3, Number 6, pp 13495-13506.

[20]. Shinde, R., and Shinde, M., (2014), "Performance Based Seismic Analysis of a Building with soft storey", International Journal for Innovative Research in Science and Technology, Volume 1, Number 3, pp 44-50.

[21]. Zameeruddin, M., and Sangle, K., (2016), "Review on recent development in the performance based seismic design of Reinforced concrete structures", Structures, Number 6, pp 119-133. 